\title{
RAZMNOŽAVANJE PAULOVNIJE KORIJENSKIM REZNICAMA
}

\section{PROPAGATION OF PAULOWNIA BY ROOT CUTTINGS}

\author{
Damir DRVODELIĆ
}

\section{Sažetak}

U rod Paulownia, porodica Paulowniaceae, ubraja se od devet vrsta i nekoliko prirodnih hibrida koji od prirode rastu u Kini. Važne vrste u ovom rodu su: P. albiflora, P. australis, P. catalpifolia, P. elongata, P. fargesii, P. fortunei, P. kawakamii i $P$. tomentosa. U novije vrijeme hibridizacijom su dobiveni brojni hibridi s ciljem povećanja brzine rasta i prirasta te otpornosti na niske temperature. U Hrvatskoj se najčešće razmnožavaju hibridi paulovnije Shan Tong i 9501 iako postoje i drugi dobiveni vlastitim selekcijama. Cilj ovoga članka je objasniti načine razmnožavanja paulovnije u prirodi i problematiku njezine invazivnosti te razmnožavanje u rasadniku pomoću autovegetativne metode makropropagacije korjenovim reznicama. Postoje tri faze zakorjenjivanja reznica: inicijacija, indukcija i ekspresija. Postoji direktna i indirektna indukcija. Najosjetljiviji trenutak je povezivanje provodnih elemenata korjenčića i dijela stanice. Uspješnost pojave korjenčića na reznici ovisi o: fiziološkom stanju matične biljke, količini šećera, metabolizmu auxina, mineralnoj ishrani, metabolizmu fenola i dr. Postoje četiri faze razmnožavanja paulovnije iz korijenskih reznica: uzimanje i dorada korijenskih reznica s matične biljke u matičnjaku, pikiranje reznica u pvc lončiće ispunjene supstratom za zakorjenjivanje, zakorjenjivanje korjenskih reznica i osnivanje novog matičnjaka. Korijenske reznice paulovnije Shang Tong i 9501 uzimane su s obzirom na polaritet na način da se donji (distalni) dio korijena rezao pod kutom od 45 stupnjeva a gornji (proksimalni) pod kutom od 90 stupnjeva. Reznice su podijeljene su na kratke $(8 \mathrm{~cm})$ i dugačke $(15 \mathrm{~cm})$. Svaka skupina reznica dodatno je podijeljena na tanke i debele na način da razlika bude na oko vidljiva. Iz svake skupine u istraživanje je uzeto po 15 reznica. Napravljen je pokus na način da jedan dio reznica bude pikiran u grijanom stakleniku 7 dana od vađenja korijena a drugi dio nakon sušenja na sobnoj temperaturi u komori rasta. Prva skupina od 60 reznica uzeta je 14. prosinca i pikirana u perforirane pvc vrećice volumena 5,0 l i u gotovi supstrat za zakorjenjivanje Klasman Steckmedium. U supstrat za zakorijenjivanje dodano je $3 \mathrm{~g} / \mathrm{l}$ gnojiva s produženim djelovanjem treće generacije Osomocote Exact Standard 5-6M formulacije 15-9-12+2MgO+TE. Reznice nisu tretirane fitohormonom niti fungicidima protiv truleži. Pikiranje reznica je obavljeno na način da je gornja površina reza od 90 stupnjeva bila u razini supstrata. Duga skupina od 60 reznica stavljena je na sušenje u komoru rasta Kambič RK-980 CH. Temperatura u komori iznosila je $21^{\circ} \mathrm{C}$ i relativna vlaga zraka od $40 \%$ što predstavlja čuvanje reznica u konstantnim sobnim uvjetima. Reznice su čuvane u komori rasta 5 dana. Pikiranje je obavljeno na isti način kao i u slučaju prve skupine reznica 21.12.2017. godine. Prvo registriranje zakorjenjivanja obavljeno je 19.02.2018. godine što znači za prvu skupinu 67 dana od pikiranja a za drugu skupinu 60 dana od pikiranja. Sušenje reznica hibrida paulovnije Shan Tong dovelo do povećanja zakorjenjivanja u svim varijantama, a posebno je izraženo kod debelih reznica duljine $8 \mathrm{~cm}$ i debelih reznica duljine $15 \mathrm{~cm}$. Može se preporučiti uzimanje debljih reznica i njihovo sušenje na sobnoj temperaturi u trajanju od 5 dana jer se dobiva značajnije veći postotak zakorjenjivanja. Pretjerana vlaga u supstratu za zakorjenjivanje korijenskim reznicama paulovnije negativno utječe na razvoj korijenskog sustava. Kod hibrida paulovnije 9501 također je utvrđeno kako sušenje reznica dovodi do povećanja zakorjenjivanja u svim varijantama, osim kod tankih reznica duljine $8 \mathrm{~cm}$ kod kojih je dobiven isti postotak zakorjenjivanja (33\%). Posebno 
je zanimljiva situacija kod debelih reznica duljine $8 \mathrm{~cm}$ kod kojih se bez sušenja nije zakorjenila niti jedna reznica a sa sušenjem čak 80 \%. Može se preporučiti uzimanje debljih reznica hibrida paulovnije 9501 i njihovo sušenje na sobnoj temperaturi u trajanju od 5 dana jer se dobiva značajnije veći postotak zakorjenjivanja. Postotak zakorjenjivanja reznica bez sušenja bio bi sigurno veći da su se uzele odmah nakon vađenja korijenskog sustava bagerom što se preporuča u praksi. U ovom slučaju minimalne temperature zraka od $-4{ }^{\circ} \mathrm{C} \mathrm{i}-5,6{ }^{\circ} \mathrm{C}$ dovele su do smrzavanja korijenskog sustava. Prosječna minimalna temperatura zraka u razdoblju od 8 . do 14 . prosinca. iznosila je svega $0,8^{\circ} \mathrm{C}$. Kod smrznutog korijena kora se odvaja rukom od drva a takve reznice ili propadaju ili tjeraju iz nižih adventivnih pupova. Korijenske reznice hibrida paulovnije Shan Tong i 9501 trebale bi se uzimati odmah nakon vađenja korijenskog sustava matične biljke a prosječne temperature zraka trebale bi biti iznad $0{ }^{\circ} \mathrm{C}$. $\mathrm{U}$ ovim istraživanjima dokazana je štetnost temperatura od $-4{ }^{\circ} \mathrm{C} \mathrm{i}-5,6^{\circ} \mathrm{C}$ na korijenske reznice jer su one dovele do njihovog smrzavanja. Najbolje kalendarsko vrijeme za vađenje korijenskih reznica, ovisno o godini, bilo bi u mjesecu ožujku. Utvrđena je mogućnost zakorjenjivanja korijenskih reznica hibrida paulovnije 9501 u običnoj vodi u kontroliranim uvjetima (bez svjetla, konstantna temperatura od $20^{\circ} \mathrm{C}$ ). Reznice su stavljene u „in vitro“ klijalicu Snijders Scientific B.V., ECD01E dana 21.12.2017. a fotografirane 21.02.2018. odnosno 62 dana od stavljanja u vodu.

KLJUČNE RIJEČI: Paulovnija Shan Tong, Paulovnija 9501, rasadnička proizvodnja, faze razmnožavanja, zakorjenjene reznice.

\section{RAZMNOŽAVANJE I INVAZIVNOST PAULOVNIJE U PRIRODI PROPAGATION AND INVASION OF PAULOWNIA IN NATURE}

U rod Paulownia pripadaju listopadne, brzo rastuće, tvrde vrste drveća iz porodice Paulowniaceae, a sastoji se od devet vrsta i nekoliko prirodnih hibrida koji od prirode rastu u Kini (Freeman i dr. 2012). Važne vrsta u ovom rodu su: P. albiflora, P. australis, P. catalpifolia, P. elongata, P. fargesii, P. fortunei, P. kawakamii i P. tomentosa (Zhu i dr. 1986).

Tipične vrste i prirodni hibridi razmnožavaju se u prirodi sjemenom (spolno, generativno, seksualno) što je osnovno svojstvo razmnožavanja preko 250000 vrsta kritosjemenjača. Kod razmnožavanja sjemenom, zbog rekombinacije svojstava, nove biljke nikada nisu genetski identične majčinskoj biljci. Paulovnije pripadaju u pionirske vrste drveća sa svim osobinama koje posjeduju te vrste (rano rađanje sjemenom, sitno i mobilno sjeme, obilni urodi svake ili svake druge godine, brza ontogeneza, stabla kratkoga životnog vijeka,...). Od svih vrsta zabilježena je u nekim dijelovima svijeta invazivnost kod vrste Paulownia tomentosa koja se očituje u mobilnosti širenja vjetrom (anemohorija) vrlo laganog i mnogobrojnog sjemena koje klija u vrlo ekstremnim ekološkim uvjetima potiskujući okolnu vegetaciju. Vrsta Paulownia tomentosa proglašena je stranom invazivnom vrstom u SAD-u od strane USDA (Jeff Stringer (http://www2.ca.uky.edu/forestryextension/kwm/paulownia.pdf). U novije vrijeme neki autori pišu o početnoj invaziji vrste Paulownia tomentosa u srednjoj Europi na osnovi njene distribucije u Austriji. Lokaliteti s vrstom Pau- lownia tomentosa potvrđeni su u toplim nizinskim područjima (ispod $450 \mathrm{~m} \mathrm{n}$. v.) i koncentrirani su u gradovima, a 90 \% svih lokaliteta zabilježeno je u gradovima s više od 100 000 stanovnika. Vrsta Paulownia tomentosa obično raste $\mathrm{u}$ manjim populacijama s manje od 10 stabala (3\% svih zapažanja) i ponaša se kao pionirska vrsta koja se invazivno širi na napuštenim urbanim staništima. Rijetko osvaja neobrasla staništa poput šumskih čistina (Essl, 2007). U Republici Hrvatskoj, na osnovu detaljnih terenskih opservacija, nije zabilježena invazivnost vrste Paulownia tomentosa iako je primijećeno njezino širenje na svega nekoliko lokaliteta ali samo u manjim grupama po nekoliko jedinki koje ne predstavljaju za sada opasnost za prirodnu vegetaciju i

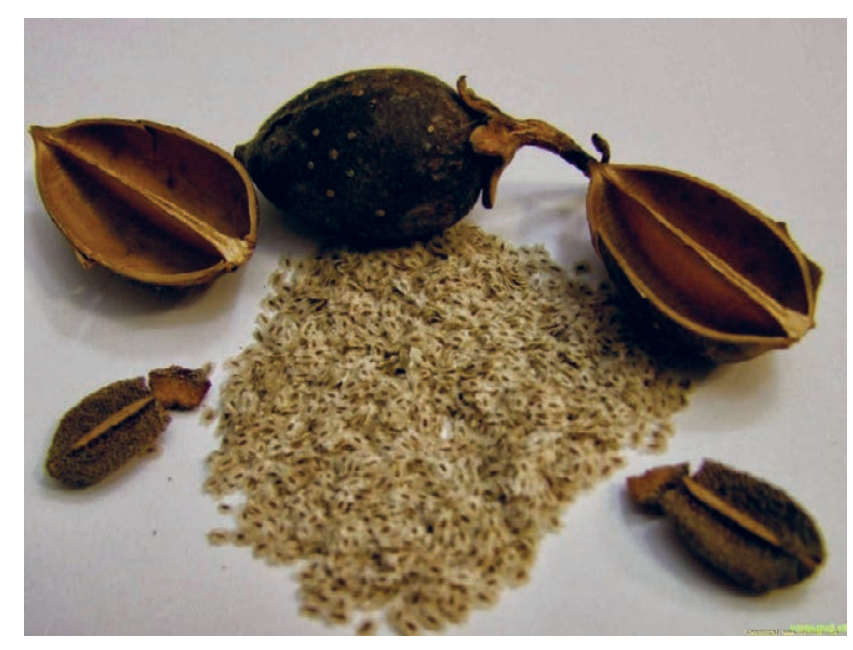

Slika 1. Plodovi i sjeme paulovnije (izvor: Petar Tadić) Figure 1. Fruits and seeds of Paulownia (source: Petar Tadic) 
ekosustav. Također nije zabilježena niti invazivnost ostalih sađenih vrsta i hibrida paulovnije. Vrsta Paulownia tomentosa ima vrlo sitno sjeme koje se nalazi u jajastim plodovima, šiljastog vrha, smeđe boje, drvenasti, $3,5-4 \mathrm{~cm}$ dugački, 2-dijelni, višesjemeni tobolci, koji su posuti lenticelama i gusto žljezdasto dlakavi; na osnovi ovijeni drvenastom čaškom.

Plodovi dozrijevaju u rujnu i listopadu i dugo ostaju na izbojcima. Otvaraju se tijekom zime i oslobađaju sjemenke, koje su vrlo uske, duguljaste, smeđe, uokolo okriljene bijelim, nepravilnim, membranastim krilcem; zajedno s krilcem su 3-4 mm dugačke, 2-2,5 mm široke, anemohorne. Masa 1000 zračno suhih sjemenki iznosi od 0,17-0,25 g. Sjeme vrste Paulownia elongata ima težinu od svega $2,17 \times 10^{-4} \mathrm{~g}$, odnosno broj čistih sjemenki u $1 \mathrm{~kg}$ kreće se u rasponu od 3700000 - 4600000 komada (Dujmović, 2014). Ovako sitno sjeme vjetar raznosi na udaljenosti većoj od $1 \mathrm{~km}$ od roditeljskog stabla. Ostale vrste roda Paulownia imaju slične plodove i sjeme kao pustenasta paulovnija ( $P$. tomentosa).

U Japanu je paulovnija poznata pod imenom „kiri“ ili „princess tree“. Uzgaja se u cijeloj Aziji već više stoljeća, a najviše iskustava imaju u Kini. Paulovnije se uzgajaju na površini od čak 2,5 milijuna hektara, pa je tako njihovo drvo jedan od jačih izvoznih proizvoda Kine. Paulovnija je izrazito medonosna. Njezin med je cijenjen, a neki mu pripisuju čak i iscjeliteljska svojstva. Ima izrazito veliku sposobnost adsorpcije ugljičnog dioksida $\left(\mathrm{CO}_{2}\right)$, čak 10 puta više od drugih vrsta stabala, te isto tako i otpušta 10 puta više kisika $\left(\mathrm{O}_{2}\right)$. Navedeno svojstvo daje mogućnost dodatnog prihoda prodajom $\mathrm{CO}_{2}$ certifikata, koje tvrtke "zagađivači" zbog ispuštanje $\mathrm{CO}_{2}$ u okoliš moraju kupovati. U Europi (Španjolska, Italija, Njemačka...) se uzgaja već više desetljeća i daje izvanredne rezultate u prinosu drvne mase i u financijskoj isplativosti.

\section{OPĆENITO 0 RAZMNOŽAVANJU PAULOVNIJE GENERALLY ABOUT PROPAGATION OF PAULOWNIA}

Vrste roda Paulownia u rasadniku se mogu razmnožavati generativnim načinom ili sjemenom ali se to ne radi zbog osjetljivosti ponika i sporog rasta biljke u mladosti. Za klijanje ponika potrebna je stalna zračna vlažnost supstrata i visoka zračna vlaga te fluorescentno svjetlo $24 \mathrm{~h}$ (pozitivno fotoblastično sjeme) ukoliko se radi u doba godine kada su kratki dani. $\mathrm{Na} 1 \mathrm{~m}^{2}$ sije se 11-12 g sjemena vrste Paulownia elongata odnosno 46000 do 50000 sjemenki. Sjeme vrste Paulownia elongata počelo je s nicanjem u stakleniku rasadnika šestoga dana od sjetve, a sve sjeme je proklijalo za 12 dana. Laboratorijska klijavost iznosila je $57,25 \%$ a rasadnička 55,25 \% (Dujmović, 2014). Biljke uzgojene sjetvom sjemena kasnije cvatu i donose plodove sa sjemenom a plantaže osnovane s takvim sadnicama daju loše rezultate u vidu neujednačene produkcije drva. Kad neki hibrid razmnožavamo sjemenom, u potomstvu nikada nećemo dobiti sadnice istoga genotipa jer kod nekontroliranog oprašivanja ne znamo od kuda je došao polen s muških cvjetova. Glavni način razmnožavanja vrsta i hibrida paulovnije u rasadniku je nespolni, vegetativni odnosno aseksualni a možemo razmnožavati autovegetativnim tehnikama makropropagacije (zagrtanjem, margotiranjem, korijenskim reznicama, zelenim vršnim reznicama od stabljike koje dobijemo iz mladih zaperaka ili zrelim (zimskim, odrvenjelim) reznicama i heterovegetativnim načinom (ksenovegetativno, cijepljenje, kalemljenje). Drugi nespolni način je razmnožavanje tehnikama mikropropagacije, kulturom tkiva ili in vitro.

Vrste roda Paulownia ne mogu se razmnožavati dijeljenjem, običnim ili lučnim polijeganjem, polijeganjem u jarak ili kineskim polijeganjem, složenim ili zmijolikim (valovitim) polijeganjem. Razmnožavanje reznicama od lista ili dijela lista te lista i pupa još nije dovoljno istraženo iako se smatra da se može razmnožiti reznicama od dijela lista s pupom. Postoje dvije najučinkovitije nespolne metode razmnožavanja paulovnije. Prva, tradicionalna metoda, je tehnika makropropagacije korjenskim reznicama a druga, suvremenija metoda je tehnika mikropropagacije u kulturi tkiva (in vitro).

\section{RAZMNOŽAVANJE PAULOVNIJE KORJENSKIM REZNICAMA PROPAGATION OF PAULOWNIA BY ROOT CUTTINGS}

Razmnožavanje korjenskim reznicama, najčešća je metoda razmnožavanja paulovnije koja se provodi se u Kini već više od pola stoljeća. Korjenske reznice se pikiraju na otvorenom $\mathrm{u}$ ukopane gredice u tlu dubine oko $15 \mathrm{~cm}$ koje se nasipaju

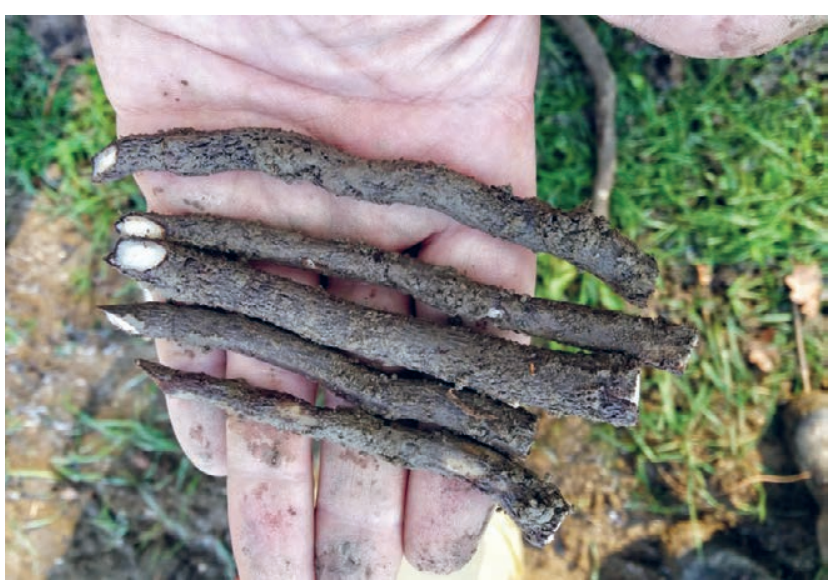

Slika 2. Izrađene korijenske reznice paulovnije s označenim polaritetom (izvor: Luka Prša, mag. ing. silv.)

Figure 2. Finished Paulownia root cuttings with marked polarities (source: Luka Prša, mag. ing. silv.) 
pijeskom. Tlo služi za zadržavanje viška vlage koju propušta pijesak. Takve ukopane gredice se prekrivaju najlonom zbog povećanja temperature i vlažnosti. Kad reznice razviju korijenski sustav i započnu s rastom nekoliko izbojaka one se vade iz pijeska i presađuju u matičnjak rasadnika. Ova metoda omogućava proizvodnju jeftinog sadnog materijala velikih količina.

\section{FIZIOLOGIJA RAZMNOŽAVANJA BILJAKA KORIJENSKIM REZNICAMA PHYSIOLOGY OF PLANT PROPAGATION BY ROOT CUTTINGS}

U svim svjetskim knjigama o razmnožavanju biljka slabo je ili nikako obrađena problematika fiziološkog aspekta razmnožavanja biljaka korijenskim reznicama. Sve počinje tijekom klijanja peludnog zrnca gdje se generativna stanica dijeli na 2 spermalne stanice. Jedna od njih oplodi jajnu stanicu i nastaje diploidna zigota iz koje se razvija klica (embrio). Druga od njih se stopi sa sekundarnom jezgrom megaspore pa nastaje triploidna stanica i razvija se hranidbeno staničje ili endosperm.

\section{RAZVITAK KLICE}

\section{DEVELOPMENT OF EMBRIO}

Zigota koja je okružena endospermom se dijeli na 2 stanice: klicu i staničje koje učvršćuje klicu i prenosi hranu do nje. Važno je istaknuti kako sama zigota pokazuje polarnost, što znači da se iz gornjeg dijela razvijaju nadzemni organi a iz donjega korijen. Polarnost ostaje zapisana do kraja života biljke. Auxin kao važan biljni hormon za zakorjenjivanje ne prolazi kroz stanične membrane već proteinske prenositelje. Postoji protein za ulaz i izlaz auxina. Proteini za izlaz nalaze se uvijek u bazalnom dijelu stanice - donjoj membrani. Auxini putuju odozgo prema dolje i dolje se nakupljaju. Tamo gdje je najveća koncentracija auxina formira se adventivno korijenje a iz dijela sa najmanjom koncentracijiom formiraju se izbojci.

\section{Postoje tri faze zakorjenjivanja:}

\section{Inicijacija-ključna faza}

2. Indukcija-dioba stanica

3. Ekspresija

Faza inicijacije traje svega od 2-3 sata do $48 \mathrm{~h}$, nema diobe stanica, auxini se nakupljaju, šećeri putuju prema dolje, počinje reprogramiranja kambija-kod jedne ili na nekoliko stanica dolazi do promjene na DNK (aktivacija i inaktivacija).

\section{Postoje dva tipa indukcije:}

1. Direktna-korijen se razvija iz kambija.

2. Indirektna-nastanak adventivnog korijenja, stvara se kalus koji se počne diferencirati, razlike nisu do kraja poznate. Najosjetljiviji trenutak je povezivanje pro- vodnih elemenata korjenčića i dijela stanice. Ksilem se mora povezati sa korjenčićem. Ponekad ne dolazi do povezivanja.

\section{Uspješnost pojave korjenčića ovisi 0 :}

- fiziološkom stanju matične biljke,

- količini šećera,

- metabolizamu auxina, što znači da li se oni iz vršnog dijela translociraju prema korijenu,

- mineralnoj ishrani (ako postoji deficijencija cinka (Zn) onda je loša sinteza auxina). Fe i Mn su bitni za enzime i

- metabolizmu fenola, koji je važan za enzime u I fazi.

Postoje 4 faze razmnožavanja paulovnije uzgojenih korijenskim reznicama (Drvodelić, 2018), kao što pokazuje ilustracija slike 5 .

\section{Uzimanje i dorada korijenskih reznica sa matične biljke u matičnjaku}

Korijenske reznice uzimaju se u matičnjaku rasadnika od prosinca do ožujka u vrijeme mirovanja vegetacije kada tlo nije smrznuto ili pod snijegom. Matične biljke s kojih se uzimaju reznice moraju biti stare jednu ili maksimalno dvije godine. Korijenski sustav matične biljke se vadi bagerom zbog učinkovitosti.

Nakon uzimanja, reznice treba očistiti od tla i tretirati fungicidom. Reznice trebaju biti debljine od 1,5-3,0 cm i duljine 10 -ak cm. Od jednog korijenskog sustava jednogodišnje matične biljke može se uzeti od 20-30 korijenskih reznica. Od dvogodišnje biljke, broj korijenskih reznica nije duplo veći.

Korijenski sustav trogodišnjih istraživanih hibrida, na obje plohe, pružao se u dubinu do maksimalno $50-\mathrm{ak} \mathrm{cm}$. Na plitko zakorjenjivanje utjecalo je i obilno površinsko navodnjavanje.

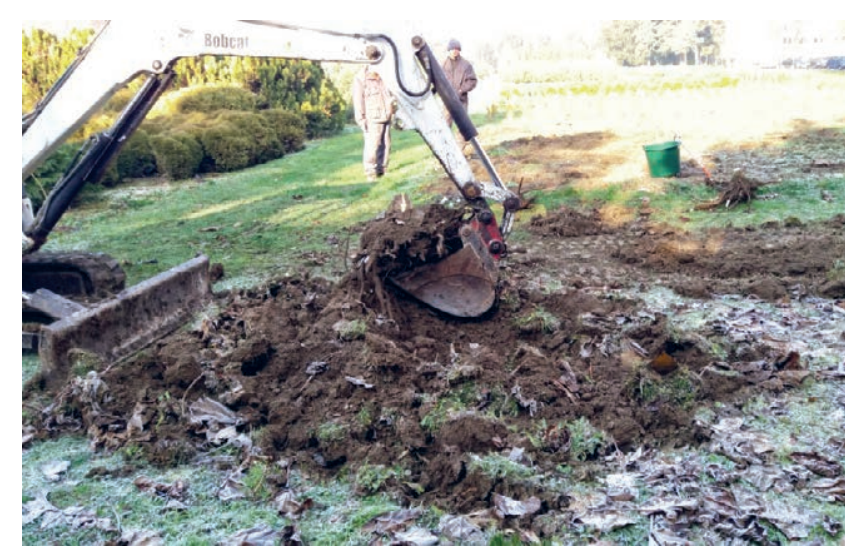

Slika 3. Vađenje trogodišnjih panjeva paulovnije bagerom dana 07.12.2017. (Izvor: Luka Prša, mag. ing. silv.)

Figure 3. Excavation of three-year old roots of paulownia by dredge on 07.12.2017. (Source: Luka Prša, mag. ing. silv.) 


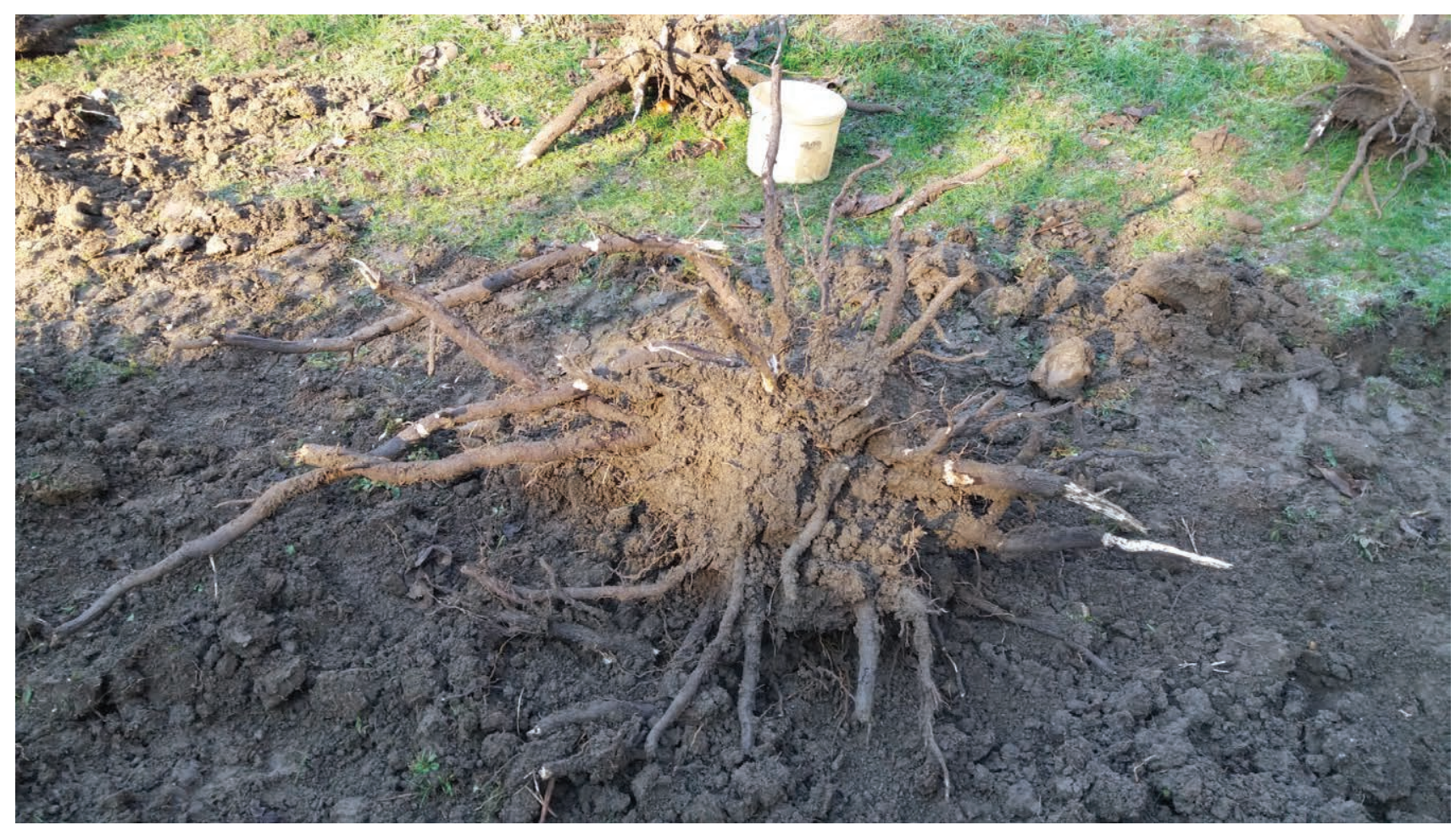

Slika 4. Izgled izvađenog korijenskog sustava trogodišnje mikorizirane sadnice paulovnije hibrida 9501 (lzvor: Luka Prša, mag. ing. silv.) Figure 4. Excavated root system of three-year old mycorrhized plants of the Paulownia hybrid 9501 (Source: Luka Prša, mag. ing. silv.)

Kod korijenskih reznica vrlo je važan polaritet kako ne bi došlo do zabune kod pikiranja. Reznice je dobro od trenutka vađenja do pikiranja držati 5-10 dana u zrako suhom prostoru. Na taj način postiže se bolje zakorjenjivanje (borba korijena za preživljavanje). Ostatak korijenskog sustava nakon uzimanja korijenskih reznica (krupnije skeletno korijenje) se ne vraća u matičnjak već ga se može staviti u prodaju kao jednogodišnji korjenjak koji postiže puno veću cijenu od sadnica uzgojenih iz korijenskih reznica. To je prva i manje značajna dobit od rasadničke proizvodnje. Takve sadnice se ne koriste za podizanje šumskih plantaža kratkih ophodnji za biomasu ili šumskih plantaža za dobivanje visokokvalitetnog tehničkog drva jer su preskupe. One se najčešće koriste za sadnju kao pojedinačno (soliterno) stablo u vrtu ili parku, za osnivanje novih stabloreda uz ulice ili avenije, uz autoceste za pročišćavanje zraka od ispušnih plinova, kao vjetrozaštitni pojas u poljoprivredi ili pojas koji umanjuje širenje invazivnih vrsta sjemena ili polena nekih visoko alergenih vrsta poput ambrozije unutar određenog poljoprivrednog usjeva. Jednogodišnji korjenak ima stopostotni primitak ako se pravilno posadi. Korijenske reznice kao repromaterijal se najčešće ne prodaju jer je ostvarena ekonomska dobit mala.

\section{Pikiranje reznica u pvc lončiće ispunjene supstratom} za zakorjenjivanje

Dio korijena bliže pridanku debla treba biti pikiran u supstrat prema gore. Proksimalni dio korijena (bliže pridanku) reže se pod kutom od $90^{\circ}$, a distalni (dalje od pridanka) pod kutom od $45^{\circ}$. To znači kako se dorađena reznica mora pikirati u kosim rezom prema dolje. Pikiranje se obavlja ručno na način da gornji ravni rez bude u razini s površinom supstrata. Za pikiranje se najčešće koriste četvrtasti pvc lončići visine 12-15 $\mathrm{cm}$ i zapremine od 1,0-1,5 l. Mogu se koristiti i perforirane pvc vrećice iste zapremine koje su jeftinije ali nemaju tako dobar učinak kao pvc lončići. Koriste se uobičajeni supstrati za zakorjenjivanje $s$ dobrim vodozračnim odnosima.

\section{Zakorjenjivanje korijenskih reznica}

Od vanjskih uvjeta za zakorjenjivanje potreban je stalno vlažan supstrat i temperatura zraka od $20^{\circ} \mathrm{C}$ i više. Zakorjenjivanje se obavlja u grijanom zaštićenom prostoru. Korjenova reznica iz zaliha vlastitih hranjivih tvari paralelno počinje iz adventivnih pupova tjerati izbojke a iz meristemskih stanica adventivne korjenčiće. Za rast izbojaka (1-3) potrebno je osigurati umjetnu hladno bijelu boju svjetlosti (4500 - 6500K) ili prirodno svjetlo (kad su dani duži) u zaštićenim objektima. Ožiljavanje korijenskih reznica je visoko, ovisno je od vrste ili hibrida ali i vanjskih uvjeta za zakorjenjivanje te iznosi prema domaćim iskustvima oko 97\%.

\section{Osnivanje novog matičnjaka}

Nakon što sadnice s 1-3 izbojka dosegnu 10-ak cm visine mogu se presađivati u matičnjak rasadnika u tre- 
nutku kada je prošla opasnost od kasnih proljetnih mrazeva što u kontinentalnom dijelu Republike Hrvatske znači iza 15. svibnja. U trenutku sadnje, može se obaviti skidanje viška izbojaka tako da ostane samo jedan ali se mogu ostaviti i svi jer se sadnice u proljeće nakon završene prve vegetacije čepiraju (režu u području vrata korijena). Sadnice se sade u matičnjak na prethodno pripremljeno tlo (riperanje, oranje, tanjuranje) i uzdignute gredice na kojima je projektiran sustav navodnjavanja kap na kap iznad koje ide crna folija širine $120 \mathrm{~cm}$. Sadnice se sade u otvore na foliji u obliku slova „X“ $\mathrm{X}$ pravilnom trokutastom rasporedu s razmakom biljke od biljke u redu od 60-80 cm i razmakom između redova od 50-60 cm. Nakon prve vegetacije, od prosinca do ožujka slijedi ponovo uzimanje reznica od korijena sadnica u matičnjaku, uzgoj sadnica i prodaja jednogodišnjeg korjenjaka. Ovim postupkom zaokružene su sve 4 faze razmnožavanja paulovnije iz korijenskih reznica.
Ovom tehnologijom se samo dio uzgojenih sadnica vraća u matičnjak rasadnika dok se ostali dio sadnica može prodati što je druga i ujedno najvažnija ekonomska dobit u rasadničkoj proizvodnji. Sadnice uzgojene korijenskim reznicama su cjenovno najprikladnije za osnivanje šumskih plantaža za dobivanje tehničkog drva, za osnivanje šumskih kultura kratkih ophodnji za dobivanje biomase, kod osnivanja plantaža za silvipastoralni način gospodarenja (paulovnija u kombinaciji s uzgojem lucerne, ljekovitog i aromatičnog bilja, raznog povrća poput rajčice, paprike, nadzemnih plodišta gljiva poput bukovača ili shiitake gljiva, podzemnih plodišta gljiva poput tartufa, pčelarenje za dobivanje visokokvalitetnog ljekovitog meda i dr.), za sadnju u cilju sprječavanja erozije tla i odnošenja hranjivih tvari na nagibima, za sadnju u svrhu zaštite poljoprivrednih usjeva od štetnog djelovanja vjetra, mraza te sjemena i polena invazivnih vrsta korova, za sadnju oko industrijskih i post industrijskih površina, kao biljka koja svojim velikim lišćem veže puno čestica prašine i smoga te pročišćava zrak, kao

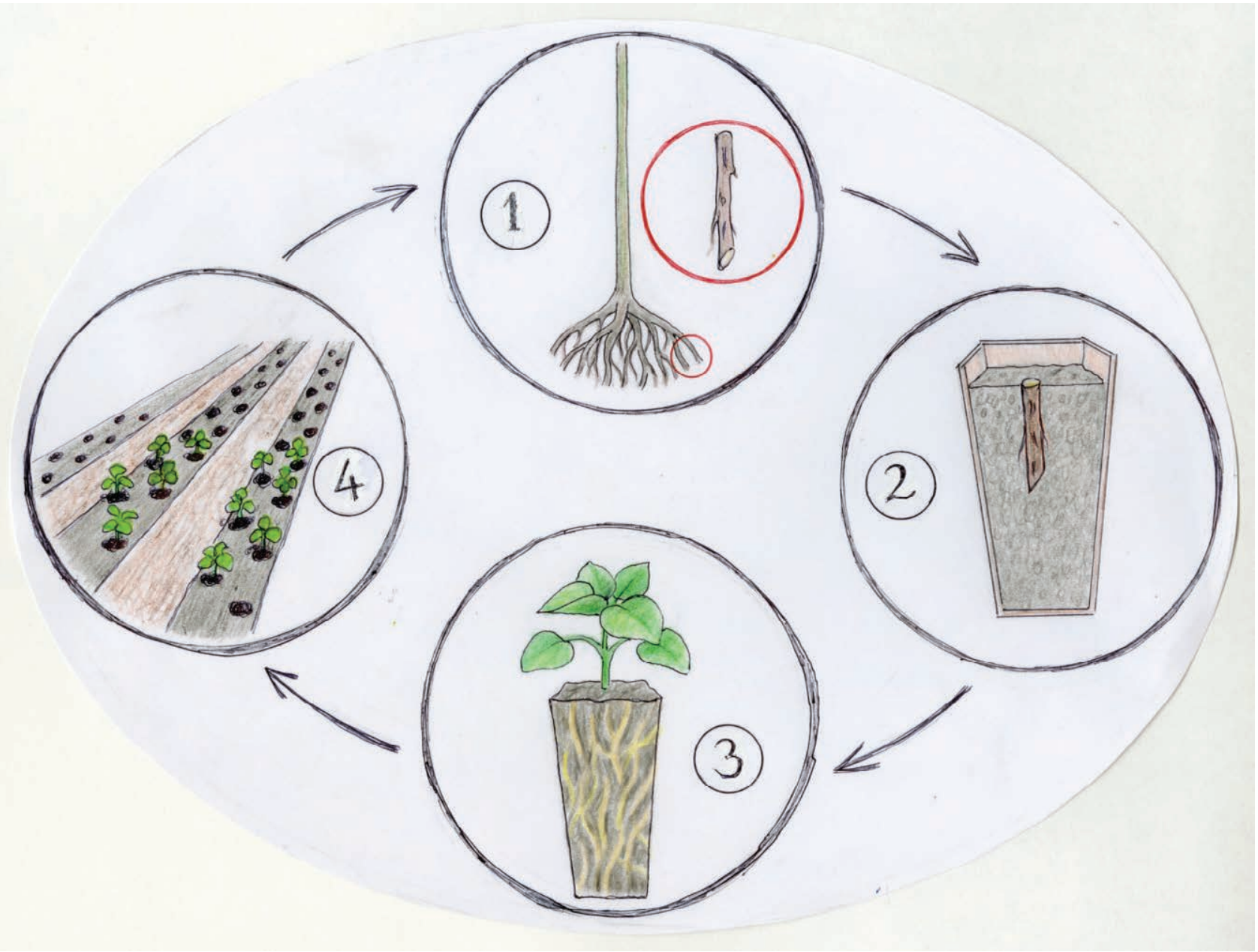

Slika 5. Faze razmnožavanja paulovnije korijenskim reznicama (izradio: doc. dr. sc. Damir Drvodelić i Petar Tadić, Paulonnija.hr) Ilustracija: akademski slikar Ivica Gabrić

Figure 5. Propagation phases of Paulownia by root cuttings (Created by: assistant professor Damir Drvodelić and Petar Tadić, Paulonnija.hr) Illustration: Academic painter Ivica Gabrić 
ukrasno soliterno stablo u vrtovima i parkovima, za podizanje novih stabloreda i aleja i dr. U novije u Republici Hrvatskoj intenzivno se najviše proučava mogućnost uzgoja tartufa na korijenu paulovnije. Kao što je navedeno riječ je o korisnim vrstama s kojim se mogu osnivati šumske plantaže s višenamjenskim i općekorisnim funkcijama. U silvipastoralnom načinu gospodarenja, svake godine dobivamo određeni prihod od sporednih proizvoda koji nisu drvna tvar što ovaj način gospodarenja čini ekonomski vrlo isplativim a još nije dovoljno zaživio u praksi u Republici Hrvatskoj. U Kini se između redova u plantažama paulovnije tradicionalno uzgajaju biljke od čijih se listova priprema vrhunski ekološki čaj. Kod kupnje sadnica hibrida paulovnije, bitno je da rasadnici izdaju certifikate i da su provjereni na tržištu.

\section{RAZMNOŽAVANJE KORIJENSKIM REZNICAMA HIBRIDA PAULOVNIJE SHANG TONG I 9501 \\ PROPAGATION BY ROOTS CUTTINGS OF THE PAULOWNIA HYBRIDS SHANG TONG AND 9501}

Nakon sječe nadzemnog dijela dvogodišnjih čepiranih sadnica u razini tla, korijenski sustav je izvađen iz tla bagerom dana 07.12.2017. godine. Korijenski sustav je ostavljen na površini 7 dana. Glavni meteorološki podaci za postaju Maksimir u razdoblju dok je korijen bio izvan tla prikazani su u tablici 1.

Korijenske reznice paulovnije Shang Tong i 9501 uzimane su s obzirom na polaritet na način da se donji (distalni) dio korijena rezao voćarskim škarama pod kutom od 45 stupnjeva a gornji (proksimalni) pod kutom od 90 stupnjeva. $\mathrm{Na}$ taj način izbjegnuta je zabuna kod pikiranja reznica.
Standardna duljina reznica se kreće od 8-15 cm. Iz tog razloga, kako bih vidjeli utjecaj duljine reznica na zakorjenjivanje, podijeljene su na kratke $(8 \mathrm{~cm})$ i dugačke $(15 \mathrm{~cm})$. Također je svaka skupina reznica podijeljena na tanke i debele na način da razlika bude na oko vidljiva. Iz svake skupine, uzeto je 15 reznica. Napravljen je pokus na način da jedan dio reznica bude pikiran u grijanom stakleniku 7 dana od vađenja korijena a drugi dio nakon sušenja na sobnoj temperaturi u komori rasta. Prva skupina od 60 reznica uzeta je 14.12. i pikirana u perforirane pvc vrećice volumena 5,0 1 i u gotovi supstrat za zakorjenjivanje reznica Klasman Steckmedium. U supstrat za zakorijenjivanje dodano je 3g/l gnojiva s produženim djelovanjem treće generacije Osomocote Exact Standard 5-6M formulacije 15-9-12+2MgO+TE. U svaku pvc perforiranu vrećicu od 51 dodano je metodom miješanja $15 \mathrm{~g}$ gnojiva. Reznice nisu tretirane fitohormonom niti fungicidima protiv truleži. Pikiranje reznica je obavljeno na način da je gornja površina reza od 90 stupnjeva na površini supstrata. Duga skupina od 60 reznica stavljena je na sušenje u komoru rasta Kambič RK-980 CH. Temperatura u komori iznosila je $21^{\circ} \mathrm{C}$ i relativna vlaga zraka od $40 \%$ što predstavlja čuvanje reznica u konstantnim sobnim uvjetima. Reznice su čuvane u komori rasta u rasta 5 dana (16.12.-21.12.2017). Pikiranje je obavljeno na isti način kao i u slučaju prve skupine reznica 21.12.2017. godine. Odmah nakon pikiranja, u stakleniku je postavljena prijenosna meteorološka postaja za mjerenje temperature i relativne vlage zraka i dana logger na kojem su priključeni geotermometri koji mjere temperaturu supstrata na dubini od 8 i $15 \mathrm{~cm}$ svakih pola sata. Prvo registriranje zakorjenjivanja obavljeno je 19.02.2018. godine što znači za prvu skupinu 67 dana od pikiranja a za drugu skupinu 60 dana od pikiranja. Rezultati zakorjenjivanja korijenskih reznica hibrida paulovnije Shang Tong i 9501 prikazani su na grafikonu 1 i 2.

Tablica 1. Meteorološki podaci za postaju Maksimir u razdoblju od 7.12.-14.12.2017. godine

Table 1. Meteorological data for Maksimir station in the period 7 Dec-14 Dec 2017

\begin{tabular}{|c|c|c|c|c|c|c|}
\hline \multirow{2}{*}{$\begin{array}{l}\text { Datum } \\
\text { Date }\end{array}$} & \multicolumn{3}{|c|}{$\begin{array}{c}\text { Temperatura zraka }\left({ }^{\circ} \mathrm{C}\right) \\
\text { Air temperature }\left({ }^{\circ} \mathrm{C}\right) \\
\end{array}$} & \multirow{2}{*}{$\begin{array}{l}\text { Relativna vlaga zraka (\%) } \\
\text { Relative air humidity (\%) } \\
\text { Mean }\end{array}$} & \multirow{2}{*}{$\begin{array}{l}\text { Temperatura tla na } 2 \mathrm{~cm}\left({ }^{\circ} \mathrm{C}\right) \\
\text { Soil temperature at } 2 \mathrm{~cm}\left({ }^{\circ} \mathrm{C}\right) \\
\text { Mean }\end{array}$} & \multirow{2}{*}{$\begin{array}{l}\text { Temperatura tla na } 5 \mathrm{~cm}\left({ }^{\circ} \mathrm{C}\right) \\
\text { Soil temperature at } 5 \mathrm{~cm}\left({ }^{\circ} \mathrm{C}\right) \\
\text { Mean }\end{array}$} \\
\hline & Max. & Min. & Mean & & & \\
\hline 07.12.2017. & 10,9 & -4 & 4,9 & 72 & 0,2 & 1,5 \\
\hline 08.12.2017. & 13,6 & 2,5 & 9 & 72 & 6,2 & 4,9 \\
\hline 09.12.217. & 9,8 & $-1,1$ & 0,2 & 92 & 0,8 & 1,9 \\
\hline 10.12.2017. & 4,7 & $-5,6$ & 1,8 & 79 & 0,1 & 1,4 \\
\hline 11.12.2017. & 15,1 & 2,9 & 13,7 & 60 & 7,2 & 6,2 \\
\hline 12.12.2017. & 16,9 & 8,4 & 11,1 & 77 & 8,9 & 8,6 \\
\hline 13.12.2017. & 8,7 & 1,8 & 3,4 & 87 & 4,7 & 5,4 \\
\hline 14.12.2017. & 13,9 & 1,5 & 7,9 & 82 & 6,7 & 6,4 \\
\hline $\begin{array}{c}\text { Prosjek } \\
\text { Average }\end{array}$ & 11,7 & 0,8 & 6,5 & 78 & 4,4 & 4,5 \\
\hline
\end{tabular}



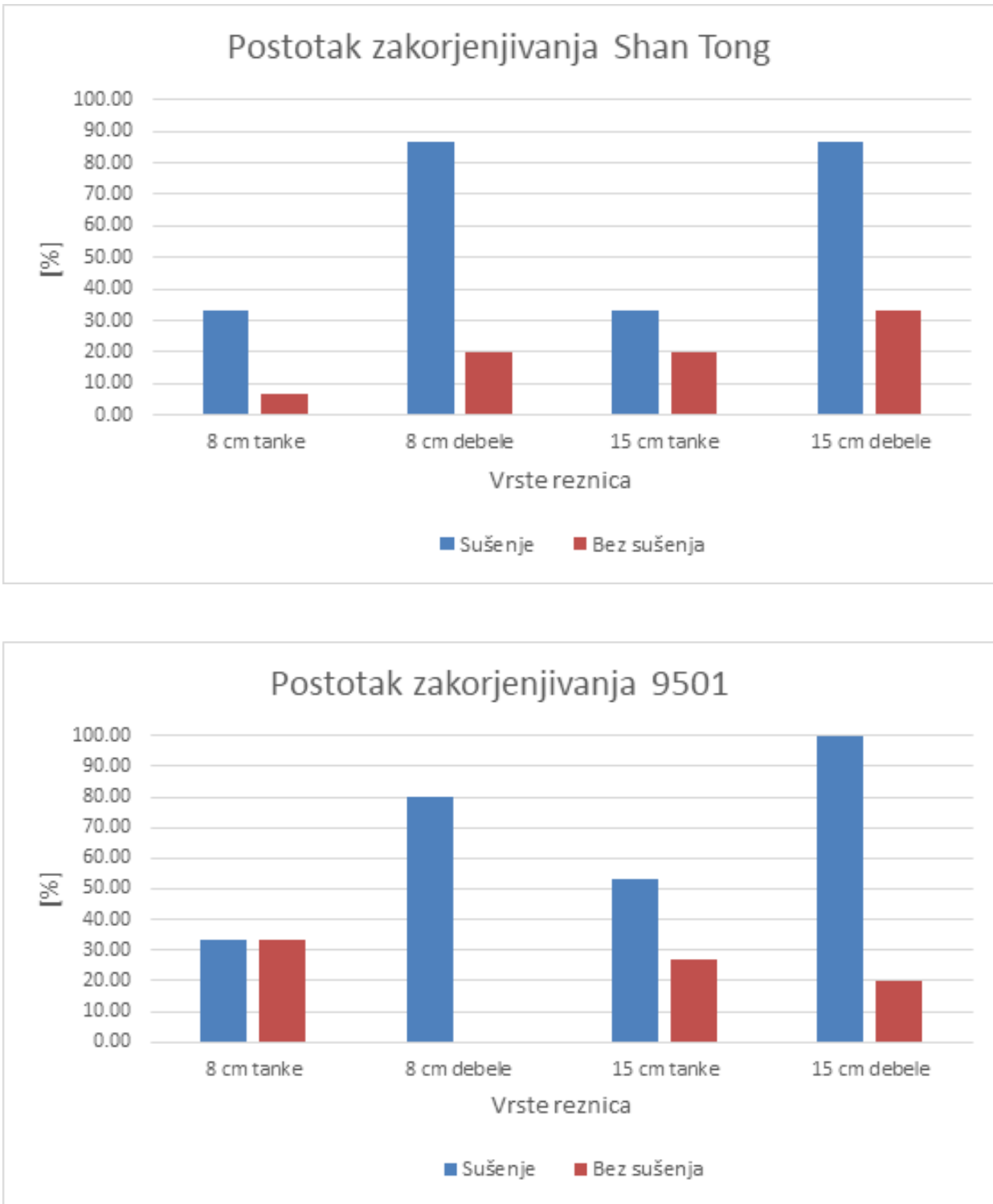

Grafikon 1. Postotak zakorjenjivanja korijenskih reznica hibrida paulovnije Shan Tong

Graph 1. Rooting percentage of the Paulownia hybrid Shan Tong by root cuttings

Grafikon 2. Postotak zakorjenjivanja korijenskih reznica hibrida paulovnije 9501

Graph 1. Rooting percentage of the Paulownia hybrid 9501 by root cuttings
Iz grafikona je jasno vidljivo kako je sušenje reznica dovelo do povećanja zakorjenjivanja u svim varijantama, a posebno je izraženo kod debelih reznica duljine $8 \mathrm{~cm}$ i debelih reznica duljine $15 \mathrm{~cm}$. Može se preporučiti uzimanje debljih reznica hibrida paulovnije Shan Tong i njihovo sušenje na sobnoj temperaturi u trajanju od 5 dana jer se dobiva značajnije veći postotak zakorjenjivanja. Pretjerana vlaga u supstratu za zakorjenjivanje korjenskih reznica paulovnije negativno utječe na razvoj korijenskog sustava.

Kao i kod prethodnog hibrida, jasno je vidljivo kako je sušenje reznica dovelo do povećanja zakorjenjivanja u svim varijantama, osim kod tankih reznica duljine $8 \mathrm{~cm}$ kod kojih je dobiven isti postotak zakorjenjivanja (33\%). Posebno je zanimljiva situacija kod debelih reznica duljine $8 \mathrm{~cm}$ kod kojih se bez sušenja nije zakorjenila niti jedna reznica a sa sušenjem čak $80 \%$. Može se preporučiti uzimanje debljih reznica hibrida paulovnije 9501 i njihovo sušenje na sobnoj temperaturi u trajanju od 5 dana jer se dobiva značajnije veći postotak zakorjenjivanja. Ovim istraživanjima utvrđen je pozitivni utjecaj sušenja reznica dva hibrida paulovnije na njihovo zakorjenjivanje nakon 67 i 60 dana što bi se trebalo provoditi i u praksi. Slična istraživanja provedena su u Kini gdje su dobiveni isti rezultati. Sušenje potiče „borbu“ reznice za preživljavanjem a može se tumačiti fiziološkim promjenama koje se događaju u samoj reznici tijekom povećanja temperature. Zakorjenjivanje bi svakako potaknulo i ubrzalo primjena fitohormona ali to nije nužno u operativi jer se povećavaju troškovi u proizvodnji.

Postotak zakorjenjivanja reznica bez sušenja bio bih sigurno veći da su se uzele odmah nakon vađenja korijenskog sustava bagerom što se preporuča u praksi. U ovom slučaju minimalne temperature zraka od $-4{ }^{\circ} \mathrm{C}$ i $-5,6^{\circ} \mathrm{C}$ dovele su do smrzavanja korijenskog sustava, posebno onog dijela koji je bio okrenut prema gore. Prosječna minimalna temperatura zraka u razdoblju od 8.12. do 14.12. iznosila je svega $0,8^{\circ} \mathrm{C}$. Kod smrznutog korijena kora se odvaja rukom 

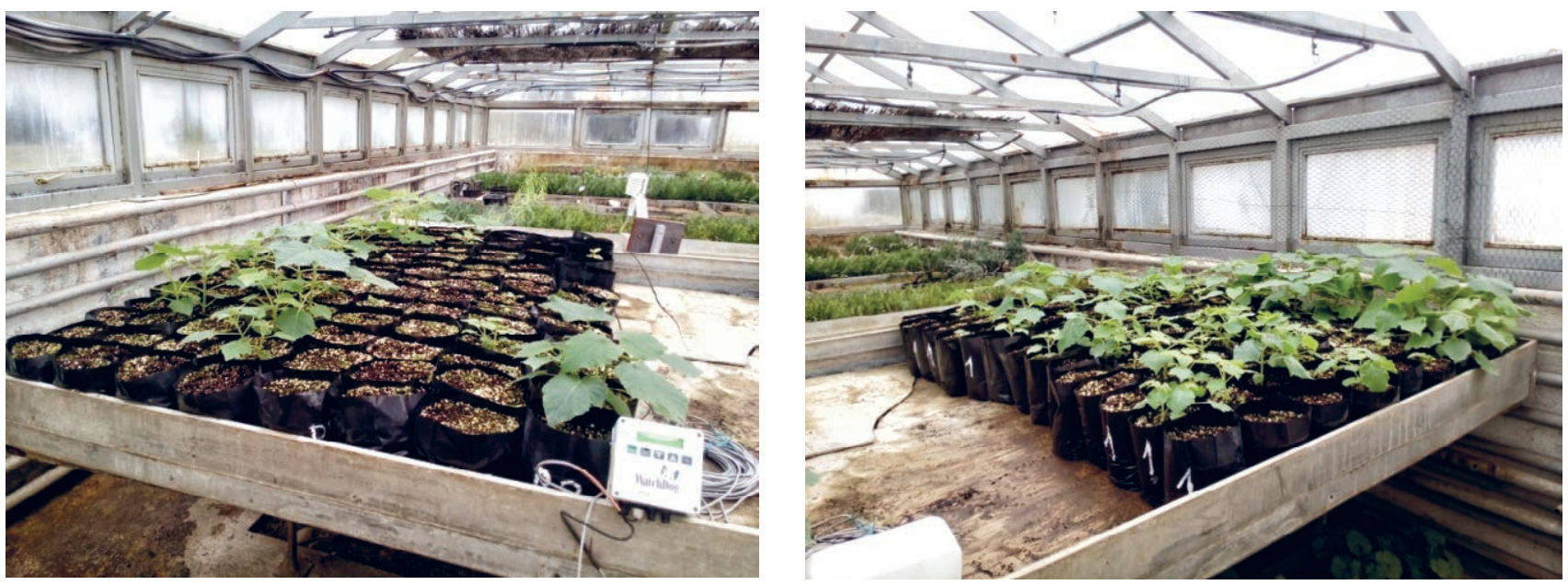

Slika 6. i 7. Zakorjenjivanje reznica paulovnije u grijanom stakleniku rasadnika „Šumski vrt i arboretum“ Šumarskog fakulteta Sveučilišta u Zagrebu (lijevo-bez sušenja, desno-sušenje). Izvor: Stjepan Dejanović

Figure 6 and 7. Rooting cuttings of Paulownia in the heated greenhouse of the «Šumski vrt i arboretum" nursery at the Faculty of Forestry of the University in Zagreb (left-no drying, right-drying). Source: Stjepan Dejanović

od drva a takve reznice ili propadaju ili tjeraju iz nižih adventivnih pupova. Svakako bi se korijenske reznice hibrida paulovnije Shan Tong i 9501 trebale uzimati odmah nakon vađenja korijenskog sustava matične biljke a prosječne temperature zraka trebale bi biti iznad $0{ }^{\circ} \mathrm{C}$. $\mathrm{U}$ ovim istraživanjima dokazana je štetnost temperatura od $-4^{\circ} \mathrm{C}$ i $-5,6$ ${ }^{\circ} \mathrm{C}$ na korijenske reznice jer su one dovele do njihovog smrzavanja. Najbolje kalendarsko vrijeme za vađenje korijenskih reznica, ovisno o godini, bilo bi u mjesecu ožujku.

Otpornost biljke a samim time i reznica na visoke temperature ovisi o vrsti, dužini trajanja visokih temperatura te periodu kaljenja (aklimatizacije). Tijekom povećanja temperature do određene granice i u određenom vremenu povećava se termostabilnost enzima i zahvaljujući tome otpornost biljaka ili reznica. Dolazi do stvaranja zaštitnih tvari (šećera, aminokiselina i dr.) koje stabiliziraju strukturu proteina ili ubrzavaju njihovu sintezu. Na otpornost biljaka i reznica prema visokim temperaturama utječe i mineralna ishrana na način da visoke koncentracije mineralnih tvari povećavaju osjetljivost na visoke temperature. Jednovalentni alkalni ioni i NO3-izazivaju bubrenje protoplazme i smanjuju njezinu otpornost dok $\mathrm{Ca}_{2}{ }^{+}$smanjuje hidrataciju i izaziva skupljanje staničnih membrana djeluje suprotno. Na otpornost biljaka i reznica prema visokim temperaturama nepovoljno utječu višak dušika (problem pretjerane aplikacije $\mathrm{u}$ rasadnicima) i nedovoljna opskrba biljaka kalcijem. Pri povećanju suše usporava se fosforilacija šećera i smanjuje se količina fosfornoorganskih spojeva, povećava se količina glukoze i fruktoze, smanjuje se količina organskih kiselina Krebsova ciklusa i količina aminokiselina. Korijen je osjetljiviji na visoke ali i niske temperature od nadzemnog dijela biljke. Kod nekih poljoprivrednih vrsta, npr. paprika, ukoliko se korijen samo jednom zalije sa hladnom vodom to izaziva termički šok za biljku a kao posljedicu ima smanjenje rasta i razvoja biljke i ukupnu produkciju plodova koji ostaju sitni.

Veći postotak zakorjenjivanja i veće visine izbojaka iz zadnja dva reda iz tretmana sušenje (slika 7), unatoč homogenim uvjetima, mogu se pripisati:

- većom temperaturom od cijevi kojima cirkulira vruća voda,

- zbog veće temperature bila je i manja vlaga supstrata,

- debljim reznicama koje pokazuju veći postotak zakorjenjivanja u odnosu na tanke i

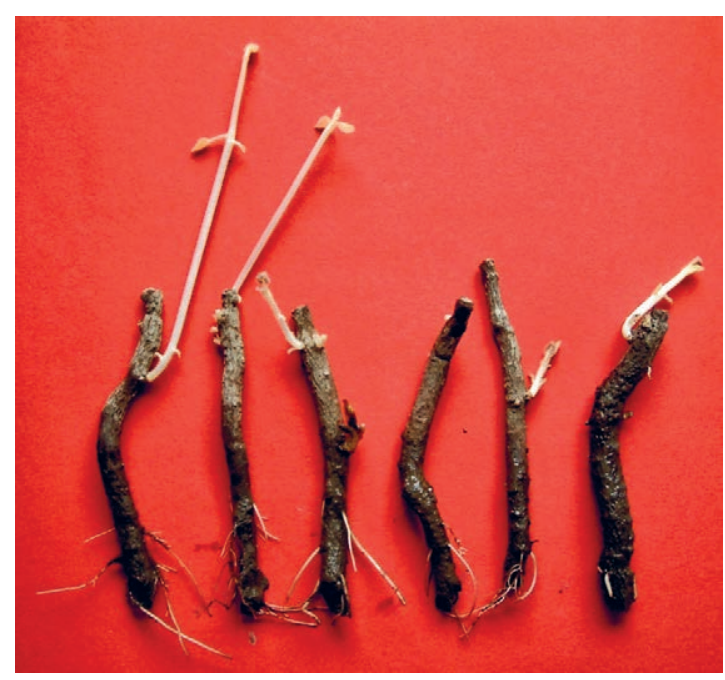

Slika 8. Zakorjenjene tanke reznice hibrida paulovnije 9501 u vodi (izvor: doc. dr. sc. Damir Drvodelić)

Figure 8. Rooted thin cuttings of the Paulownia hibrid 9501 in water (source: assistant professor Damir Drvodelić) 


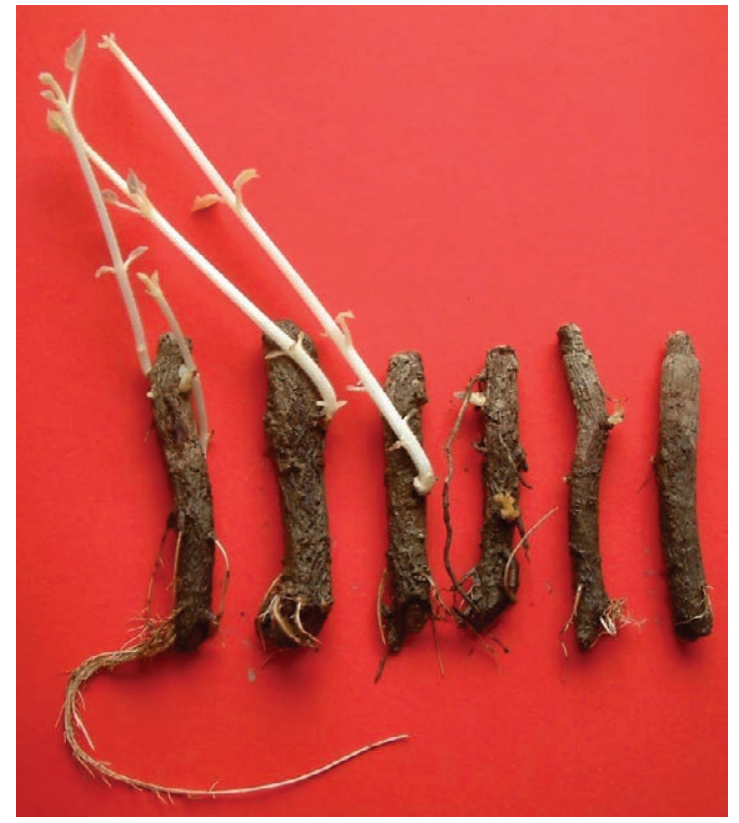

Slika 9. Zakorjenjene debele reznice hibrida paulovnije 9501 u vodi (izvor: doc. dr. sc. Damir Drvodelić)

Figure 9. Rooted thick cuttings of the Paulownia hibrid 9501 in water (source: assistant professor Damir Drvodelić)

- južnom stranom staklenika gdje je prisutno jače zagrijevanje od popodnevnog sunca.

Prilikom daljnjih istraživanja zakorjenjivanja, mora se obratiti pažnja na navedene uvjete.

\section{RAZMNOŽAVANJE KORIJENSKIH REZNICA HIBRIDA PAULOVNIJE 9501 U VODI PROPAGATION OF ROOT CUTTINGS OF THE PAULOWNIA HYBRID 9501 IN WATER}

U laboratoriju za šumsko sjemenarstvo i rasadničarstvo na Zavodu za ekologiju i uzgajanje šuma Šumarskog fakulteta
Sveučilišta u Zagrebu postavljen je zanimljivi pokus zakorjenjivanja korijenskih reznica hibrida paulovnije $9501 \mathrm{u}$ običnoj vodi. Korijenske reznice stavljene su u pvc posudu s običnom vodom u kontrolirane uvjete u zatvorenoj klijalici Snijders Scientific B.V., ECD01E. U klijalici su namješteni uvjeti bez svjetla (zbog rasta i razvoja korijena) i konstantna temperatura od $20^{\circ} \mathrm{C}$. Reznice su stavljene u klijalicu dana 21.12.2017. a fotografirane 21.02.2018. odnosno 62 dana od stavljanja u vodu. Aktivirani izbojci rasli su u uvjetima bez svjetla zbog čega je došlo do pojave etiolacije što je biljni sindrom uvjetovan nedostatkom svijetla a manifestira se u obliku žućkastih listova i abnormalno izduženih internodija (primjer je proizvodnja šparoge). Na slikama 8. i 9. prikazan je uzorak tankih i debelih reznica podjednake duljine zakorijenjen u čistoj vodi.

\section{LITERATURA}

\section{REFERENCES}

- Drvodelić, D., 2018: Plantažni uzgoj paulovnije. Gospodarski list (mali gospodarski savjetnik 15.03.2018.)

- Dujmović, M., 2014: Morfološko-biološke značajke i ispitivanje klijavosti sjemena paulovnije (Paulownia elongata S. Y. Hu.). Završni rad. Šumarski fakultet Sveučilišta u Zagrebu, 35 str.

- Essl, F., 2007: From ornamental to detrimental? The incipient invasion of Central Europe by Paulownia tomentosa. Preslia, 79: 377-389.

- Freeman, C. C., R. K. Rabeler, W. J. Elisens, 2012: Flora of North America, Provisional Publication,Vol. 17. http://floranorthamerica.org/files/Paulowniaceae04\%20SI.CH\%20for\%20 web.pdf

- Zhu, Z. H., C. J. Chao, X. Y. Lu, Y. G. Xiong, 1986:: Paulownia in China: Cultivation and Utilization, Asian Network for Biological Sciences and International De- velopment Research Centre, Singapore, 1-65 str.

- http://www2.ca.uky.edu/forestryextension/kwm/paulownia.pdf (08.02.2016.)

\section{Summary}

The genus Paulownia, family Paulowniaceae, contains about nine species and several natural hybrids which are native to China. Some important species in this genus include $P$. albiflora, $P$. australis, $P$. catalpifolia, P. elongata, $P$. fargesii, $P$. fortunei, $P$. kawakamii and P. tomentosa. More recently, numerous hybrids have been obtained by hybridisation for the purpose of increasing the rate of growth and increment, as well as develop resistance to low temperatures. In Croatia, the most commonly propagated are the Paulownia hybrids Shan Tong and 9501, although there are also other hybrids obtained by selections in some "in vitro" laboratory. The goal of this article is to explore different propagation methods of Paulownia in the nature, the problem of its invasiveness and nursery propagation by means of autovegetative macropropagation method from root cuttings. There are three phases of rooting the cuttings: initiation, induction and expression. There is direct and indirect induction. The most sensitive moment is the connecting of the conductive elements of small roots with parts of a cell. The success of root development on the cutting depends on the physiological status of the parent plant, sugar quantity, auxin metabolism, mineral nutrition, phenol metabolism and others. There are four stages 
of Paulownia propagation from root cuttings: digging out and finishing of root cuttings from the parent stock, pricking out the cuttings into plastic containers filled with potting media, rooting the cuttings and the establishment of a new parent stocks. The Paulownia root cuttings Shang Tong and 9501 were taken with regard to the polarity in the following way; the bottom (distal) part of the root was cut at an angle of 45 degrees and the upper (proximal) part was cut at an angle of 90 degrees. The cuttings were divided into short $(8 \mathrm{~cm})$ and long $(15 \mathrm{~cm})$ cuttings. Each group of the cuttings was additionally divided into thin and thick cuttings, making the difference visible to the naked eye. A total of 15 cuttings were taken from each group for the purpose of our research. In the experiment, one part of the cuttings was pricked out in a heated greenhouse 7 days after root excavation and the other part of the cuttings was pricked out after drying at room temperature in the plant growth chamber. The first group of 60 cuttings was taken on December 14th and pricked out in perforated 5.01 plastic bags filled with ready-made Klasman Steckmedium rooting medium. The rooting medium was enriched with 3g/l of Osmocote Exact Standard 5-6M formulation 15-9-12+2MgO+TE, the 3rd generation of controlled release fertilizers. The cuttings were not treated with a phytohormone or rot prevention fungicides. The cuttings were pricked out in such a way that the upper surface of the cut at 90 degrees was at the level of the potting medium. The second group of 60 cuttings was dried in the Kambić RK$980 \mathrm{CH}$ growth chamber. The chamber temperature was $21^{\circ} \mathrm{C}$ and the relative air humidity was $40 \%$, which equalled storage of the cuttings under constant room conditions. The cuttings were kept in the growth chamber for 5 days. Pricking out was performed on December 12th, 2017 in the same way as the first group of cuttings. The first rooting registration was done on February 19th, 2018, which in the case of the first group means 67 days after pricking out and for the second group 60 days after pricking out. Drying the Paulownia Shang Tong hybrid cuttings increased the rooting success in all the variants, and was particularly evident in thick cuttings $8 \mathrm{~cm}$ long and thick cuttings $15 \mathrm{~cm}$ long. Selecting thicker cuttings and drying them at room temperature for 5 days can be recommended because this procedure yields a significantly higher rooting percentage. Excessive moisture in the potting medium used for the Paulownia root cuttings negatively affects root system development. It was also confirmed that drying the Paulownia hybrid 9501 cuttings increases the rooting success in all the variants, with the exception of thin cuttings $8 \mathrm{~cm}$ long, where the rooting percentage was the same (33 $\%$ ). Thick cuttings $8 \mathrm{~cm}$ long present a particularly interesting case, where not one single cutting which was not dried took root, while as many as $80 \%$ of cuttings took root after being dried. Taking thicker cuttings of the Paulownia 9501 hybrid and drying them at room temperature for 5 days can be recommended, because this procedure yields a significantly higher rooting percentage. The rooting percentage of cuttings without drying would certainly be higher if the cuttings had been taken immediately after the root system was dug out with a dredge, as recommended in practice. In this case, the minimal air temperatures of $-4{ }^{\circ} \mathrm{C}$ and $-5.6^{\circ} \mathrm{C}$ caused the root system to freeze. The average minimal air temperature in the period from December 8 th to December 14 th was only $0.8^{\circ} \mathrm{C}$. When the root is frozen, the bark is separated from the wood manually, and such cuttings either decay or sprouting from the lower adventitious buds. The root cuttings of the Paulownia hybrids Shan Tong and 9501 should be taken immediately after the root system of the parent plant is dug out, while the average air temperature should be above $0{ }^{\circ} \mathrm{C}$. Our studies confirmed the harmful effect of temperatures from $-4^{\circ} \mathrm{C}$ and $-5.6^{\circ} \mathrm{C}$ on root cuttings, as such temperatures caused the cuttings to freeze. The best calendar period for digging out root cuttings, depending on the year, should be in March. It was confirmed that the root cuttings of Paulownia hybrid 9501 can also be rooted in ordinary water under controlled conditions (no light, constant temperature of $20^{\circ} \mathrm{C}$ ). The cuttings were placed in “in vitro" Snijders Scientific B.V., ECD01E germination table on December 21st, 2017, and were photographed on February 21st, 2018, or 62 days after being placed in the water.

KEY WORDS: Paulownia Shan Tong, Paulownia 9501, nursery production, propagation phases, rooting cuttings. 